\title{
Tourists' Satisfaction towards Bao Loc City, Vietnam
}

\author{
Ha Nam Khanh GIAO', Tran Dieu HANG ${ }^{2}$, Le Thai SON ${ }^{3}$, Dinh KIEM ${ }^{4}$, Bui Nhat VUONG ${ }^{5}$
}

Received: April 21, 2020 Revised: May 03, 2020 Accepted: June 07, 2020

\begin{abstract}
Bao Loc City is the new tourism destination in Lam Dong province, Vietnam, where more and more tourists have been drawn to pay a visit. This study aims to test the correlative impact of tourism service quality factors on satisfaction of the tourists who have visited Bao Loc City. The key theory used in this study is SERVQUAL scale. The survey sample consists of 350 tourists who stayed overnight in Bao Loc City in the last quarter of 2019; 315 valid survey questionnaires could be used for the analysis. The research applied Cronbach's Alpha, exploratory factor analysis (EFA), confirmatory factor analysis (CFA), structural equation modeling (SEM), and bootstrap test. The results show that the satisfaction of the tourists who have visited Bao Loc City has been affected statistically by three factors: (1) Responsiveness; (2) Reliability; and (3) Empathy, which were ranked by descending importance. Surprisingly, the research found that Tangibles and Assurance do not have an impact on tourists' satisfaction towards Bao Loc City. The research formulates some suggestions to the city policy-makers and the tourism businesses management in Bao Loc City in order to enhance tourists' satisfaction through improving the tourism service quality at Bao Loc City.
\end{abstract}

Keywords : Bao Loc City, Service Quality, Structural Equation Modelling (SEM), Tourists' Satisfaction, Vietnam

JEL Classification Code: C12, C83, L83, Z32

\section{Introduction}

There are many studies on services and consumer behavior (Giao, 2004a, 2004b, Giao, 2018, 2018a, 2018b, 2018c, 2018d, 2018e, 2018f, 2018g, 2018h; Giao, 2019a, 2019b, 2019c, 2020; Giao, Hoai, \& Vinh, 2019, Giao, Vuong \& Quan, 2019; Vuong \& Giao, 2020; Giao, Trung \& Truong,

${ }^{1}$ First Author and Corresponding Author. Dean, Faculty of Air Transport, Vietnam Aviation Academy, Vietnam [Postal Address: A65 Nam Thong 1 Town, Phu My Hung Zone, Tan Phu Ward, District 7, Ho Chi Minh City, 729000, Vietnam] Email: khanhgiaohn@yahoo. com

${ }^{2}$ Lecturer, Faculty of Air Transport, Vietnam Aviation Academy, Vietnam. Email: hangtd@vaa.edu.vn

${ }^{3}$ Visiting Lecturer, Faculty of Air Transport, Vietnam Aviation Academy, Vietnam. Email: sonphoto@gmail.com.

${ }^{4}$ Visiting Lecturer, Faculty of Air Transport, Vietnam Aviation Academy, Vietnam. Email: dinh.kiem@gmail.com

${ }^{5}$ Lecturer, Faculty of Air Transport, Vietnam Aviation Academy, Vietnam. Email: nhatvuonga1@gmail.com

(c) Copyright: The Author(s)

This is an Open Access article distributed under the terms of the Creative Commons Attribution Non-Commercial License (http://Creativecommons.org/licenses/by-nc/4.0/) which permits unrestricted noncommercial use, distribution, and reproduction in any medium, provided the original work is properly cited.
2019, Giao, Vuong, Huan, Tushar \& Quan, 2020), on tourism and hospitality (Giao \& Hao, 2011; Giao \& Son, 2012, 2014; Giao, Kiem, Son, \& Dung, 2018; Giao \& Son, 2018; Son \& Giao, 2018;), and on destination (Giao \& Sang, 2018; Giao $\&$ Son, 2015;). The research confirms that destinations that are attractive, not only for their natural landscapes, but also in terms of cultural differences, could draw many tourists.

Bao Loc is one of two cities of Lam Dong province. When it comes to the Central Highlands province of Lam Dong, tourists will immediately think of Da Lat city, which has long been the most popular location in the region for hundreds of years. However, many tourists have discovered more beautiful places such as Dambri waterfall of Bao Loc City, tea plantation or Linh Quy Phap An, which is known as a pagoda in the clouds, a sunset for the soul. Dambri is the most imposing waterfall in the Central Highlands; the waterfall is attached to legends and unique cultural characteristics of ethnic people in the region such as Co Ho and Chau Ma, and Gong culture. It is a special characteristic on which to develop community tourism.

Linh Quy Phap An pagoda was built in 2006, but it is only known since the past two years; the pagoda features breathtaking views from the mountaintop and offers a Sangri- 
La-like atmosphere. Bao Loc is the largest tea-growing area in Lam Dong, in particular, and in the Central Highlands and South Vietnam, in general. Tam Chau tea hill will become an agricultural tourism area which grows organic tea, and features vegetable gardens, and flower hills. Besides, Bat Nha Monastery is a quiet, peaceful place with hidden huts in the green pine forest. Amitabha Temple is the highlight of Bao Loc, with beautiful mountains and wild waterfalls. In addition, Tam Hop Waterfall, which is also called The Three Gorges Waterfall, is located at the back of the Amitabha Temple, a beautiful place with cool waterfalls, between the forest full of grass and flowers. People still have other natural landscapes to visit such as Ta Ngao 7-level waterfall, Dong Nai lake, Chocolate lake, and other spots (Foody, 2019).

There was a time, cross-country visitors, especially rich and luxurious merchants, 'stylish' and fashionable guests domestic and from abroad have been once infatuated with Bao Loc Silk! From branches of strawberries and silkworms worked by skillful and diligent hands, people have created a shiny and smooth product, giving users a certain standing in society. Bao Loc silk weaving industry has imposed itself in the domestic and world markets a century ago. At Bao Loc, there are 23 silk-weaving enterprises, including seven mechanical-reeling enterprises, eight automatic-reeling enterprises, and eight silkweaving enterprises. The annual production of silk in Bao Loc City reaches about 1,000 tons, and 5.6 million $\mathrm{m}^{2}$ of silk clothes. In addition to reeling, the cultivation of mulberry (a precious raw material) has also increased significantly; currently, mulberry's cultivated land area in Bao Loc is over 2,000 ha. To develop the silk industry, City People's Committee of Bao Loc established a trademark for Bao Loc Silk and was granted a Trademark Registration Certificate by the National Office of Industrial Property; there have been seven businesses granted the rights to use the Silk trademark.

According to Vietnam National Administration of Tourism (VNAT) statistics (VNTA, 2000), the number of visitors to Bao Loc grew significantly in the period from 2015 to 2020 , reaching an average growth rate of about $20 \%$ per year. In 2017 , the total number of visitors to Bao Loc reached 700,000, of which international visitors accounted for $25 \%$, and the number reach almost 1 million visitors at the end of 2019. The average number of guests staying in Bao Loc is around 1.15 days, and predicted to rise in 2020s. But some of Bao Loc tourism products and service quality have stagnated, and may discourage tourists to stay. Therefore, the study of the factors of service quality that affects visitor satisfaction is essential nowadays.

\section{Literature Review}

\subsection{Travel Destinations}

According to Medlik and Middleton (1973), tourism products are important to the overall experience, from the time people leave their homes until they return. Vietnam Tourism Law declares: "The tourism product is the set of services needed to satisfy the needs of tourists during the trip." According to the United Nations World Tourism Organization (UNWTO), tourists include: international tourist; internal tourist; domestic tourist and national tourist, of which domestic tourists include internal tourists and international tourists. These concepts are also found in Giao (2011); Giao and Son (2014); Giao and Binh, (2011), (2014); Giao, Binh and Tung (2014); Giao, Hoan, Dung, Vinh and Anh (2014).

According to Rubies (2001), a travel destination is a geographic area which contains resources for tourism, attractions, infrastructure, equipment, service providers, other support and management organizations they interact with, that provide visitors with the experience they expect at the destination they have chosen. Giao (2011) argued that a destination for tourism is a point that we can perceive by geographic boundaries, politics or economy, and a place where tourism resources are attractive, capable of attracting and satisfying the needs of tourists.

Gartrell (1994) defined destinations as geographic regions that have attributes, features, attractions and services to attract potential users. In a strategic perspective, Buhalis (2000) argued that the destination is a mix of service products, providing an integrated experience for consumers. Page and Connell (2006) defined a destination as a mixture of pre-packaged products, services, accessibility, attraction, facilities, activities and support services. As such, a destination must have a certain range of facilities and services to offer visitors. Consequently, today, many cities and destinations are continually maintaining and improving their facilities to maintain competitive advantage, thereby allowing the destination to continue to maintain its market position.

\subsection{Quality of Service and Customer Satisfaction}

Service is the result of interactions between suppliers and customers, as well as by suppliers' activities to meet consumer demand (ISO 9004-2: 1991E). According to Lovelock and Wirtz (2004), service is an economic activity that creates value and benefits the customer in a certain place and time by responding to the wishes of the receiver.

TCVN ISO 9000:2000 defined 'Quality' as “the level of a set of inherent characteristics of a product, system, or process to meet the requirements of customers and stakeholders." When visitors travel, they must use the provider's travel products and services, the results of the service provided through the interaction between the provider and the visitor, as well as by the activities of the supplier to meet the needs of the consumer (ISO 9004-2: 1991E). To measure visitor satisfaction, the quality of service is measured, as in the 
consumption process, the quality of service is reflected in the interaction between suppliers and visitors (Svensson, 2002).

Many researchers agree with Parasuraman, Zeithamlm and Berry $(1985,1988)$ who argued that service quality is determined by the difference between customer expectations of service and their evaluation of the service they receive. One of the primary theories on service quality is the theory of distance analysis (Zeithaml, Parasuraman, \& Berry, 1990), which posits that consumers are satisfied when they evaluate the quality of service they receive equating or exceeding their expectations. Giao and $\mathrm{Vu}$ (2011) summarized simple customer satisfaction as a meeting point or area that overlaps between the ability of the business and the needs of the customer; or the level of a person's sense of state begins with comparing the results obtained from the product/service with his or her expectations.

Giao and Son (2012) conducted a measure of service quality and customer satisfaction at the Dalat Flower Festival with the SERVQUAL scale (Cronin \& Taylor, 1992) with five components using a 5-point likert scale: (1) Tangible; (2) Empathy; (3) Responsiveness; (4) Reliability; and (5) Assurance.

\subsection{Research Models}

The proposed model is based on the theoretical and practical premises of Bao Loc:

$f=\{$ Assurance, Reliability, Empathy, Responsiveness, Tangible $\}$.

Hypotheses should be tested:
$\mathrm{H}_{1}$ : Assurance has a positive effect on tourists' satisfaction $\mathrm{H}_{2}$ : Reliability has positive effect on tourists' satisfaction

$\mathrm{H}_{3}$ : Empathy has a positive effect on tourists' satisfaction

$\mathrm{H}_{4}$ : Response has a positive effect on tourists' satisfaction

$\mathrm{H}_{5}$ : Tangibles has a positive effect on tourist's satisfaction

\section{Research Methodology}

\subsection{Qualitative Research}

In the preliminary study, the author relied on a transformational scale from the SERVQUAL scale, and conducted a preliminary study with a focus group discussion to develop a preliminary scale and develop a questionnaire. From the preliminary questionnaire, the author interviewed 50 visitors, then consulted experts to adjust the wording for the questionnaire to understand and appropriate.

From the results of the preliminary study, after the adjustment, the official scale of research concepts was designed, preparing for quantitative research. Specific observations on measurements used 5-point Likert scale rating, from $1=$ totally disagree to $5=$ completely agree.

\subsection{Survey}

The survey was conducted in the last quarter of 2019 when 350 questionnaires were distributed in Bao Loc City with convenient sampling method. The interviewees are domestic and foreign visitors who are staying overnight in Bao Loc City. 325 copies were used for the analysis, 25 were rejected because of incomplete information. The sample characteristics are presented in Table 1.

Table 1: Sample characteristics

\begin{tabular}{|l|l|c|c|}
\hline \multicolumn{1}{|c|}{ Criteria } & & Amount & Ratio (\%) \\
\hline \multirow{5}{*}{ Gender } & Male & 112 & 34.46 \\
\cline { 2 - 4 } & Female & 213 & 65.54 \\
\hline \multirow{5}{*}{ From } & North of Vietnam & 46 & 14.15 \\
\cline { 2 - 4 } & Central of Vietnam & 115 & 35.38 \\
\cline { 2 - 4 } & South of Vietnam & 53 & 16.31 \\
\cline { 2 - 4 } & Foreign countries & 101 & 31.08 \\
\hline \multirow{5}{*}{ Objective } & Sight-seeing & 120 & 36.92 \\
\cline { 2 - 4 } & Recreation & 118 & 36.31 \\
\cline { 2 - 4 } & Visiting relatives & 15 & 4.62 \\
\cline { 2 - 4 } & Business & 67 & 20.62 \\
\cline { 2 - 4 } & Others & 5 & 1.54 \\
\hline
\end{tabular}




\subsection{Quantitative Research}

Cronbach's Alpha testing is used to eliminate the rubbish before conducting factor analysis. Variables with a Corrected item total correlation less than 0.3 will be rejected. A reliability scale is good as it varies in the range [0.70-0.80]. If Cronbach's Alpha $\geq 0.60$, that is an acceptable scale of reliability (Giao \& Vương, 2019).

Exploratory Factor Analysis (EFA) is used to identify groups of criteria for assessing service quality at Bao Loc tourism destinations. EFA is used to abbreviate a $\mathrm{k}$ set of observed variables into a set $\mathrm{F}(\mathrm{F}<\mathrm{k})$ of the more significant factors. The basis of this reduction is based on the linear relationship of the factors with the observed variables.

The Confirmatory Factor Analysis (CFA) allows us to test how well we measure the measure variables representing constructs. The CFA method is used to confirm the univariate, multivariate, convergent and discriminant values of the scale of service quality.
Structural equation modeling (SEM) is used to test the proposed model. The structural model specifies the relationship between latent variables (a concept measured on many observable variables).

\section{Empirical Results}

\subsection{Scale Measurement and Measurement Model}

Cronbach's Alpha results for Bao Loc's service quality scales are shown in Table 2, item total correlation is greater than 0.3 . The scale meets the reliability, and is used in the EFA (Giao \& Vương, 2019).

\subsection{Exploratory Factor analysis}

Exploratory Factor Analysis (EFA) results show that five factors were extracted at Eigenvalue 1.256 and the extraction variance was $59.351 \%$. Observed variables are grouped into factors as the initial assumption, with reliability in Table 3.

Table 2: Results of Cronbach's Alpha measure of service quality in Bao Loc

\begin{tabular}{|c|l|c|c|}
\hline & \multicolumn{1}{|c|}{ SCALE } & NUMBER OF ITEMS & RELIABILITY \\
\hline 1 & Assurance & 3 & 0.758 \\
\hline 2 & Reliability & 4 & 0.702 \\
\hline 3 & Responsiveness & 4 & 0.828 \\
\hline 4 & Tangibles & 5 & 0.695 \\
\hline 5 & Empathy & 4 & 0.711 \\
\hline 6 & Satisfaction & 4 & 0.747 \\
\hline
\end{tabular}

Table 3: Factor Matrix

\begin{tabular}{|c|c|c|c|c|c|}
\hline & & & ompon & & \\
\hline & 1 & 2 & 3 & 4 & 5 \\
\hline $\mathrm{ASS}_{\text {, }}$ & & & 0.853 & & \\
\hline $\mathrm{ASS}_{2}$ & & & 0.727 & & \\
\hline $\mathrm{ASS}_{3}$ & & & 0.856 & & \\
\hline $\mathrm{REL}_{1}$ & & & & 0.681 & \\
\hline $\mathrm{REL}_{2}$ & & & & 0.787 & \\
\hline $\mathrm{REL}_{2}^{2}$ & & & & 0.659 & \\
\hline $\mathrm{REL}_{4}$ & & & & 0.728 & \\
\hline $\mathrm{RES}_{1}$ & & 0.711 & & & \\
\hline $\mathrm{RES}_{2}$ & & 0.724 & & & \\
\hline $\mathrm{RES}_{3}$ & & 0.716 & & & \\
\hline $\mathrm{RES}_{4}$ & & 0.623 & & & \\
\hline TAN $_{1}$ & 0.796 & & & & \\
\hline $\mathrm{TAN}_{2}$ & 0.732 & & & & \\
\hline $\mathrm{TAN}_{3}$ & 0.756 & & & & \\
\hline TAN $_{4}$ & 0.667 & & & & \\
\hline TAN $_{5}$ & 0.828 & & & & \\
\hline$E M_{1}$ & & & & & 0.792 \\
\hline $\mathrm{EMP}_{2}$ & & & & & 0.724 \\
\hline $\mathrm{EMP}_{3}$ & & & & & 0.735 \\
\hline $\mathrm{EMP}_{4}$ & & & & & 0.713 \\
\hline
\end{tabular}


Ha Nam Khanh GIAO, Tran Dieu HANG, Le Thai SON, Dinh KIEM, Bui Nhat VUONG /

Journal of Asian Finance, Economics and Business Vol 7 No 7 (2020) 269 - 277

\subsection{Confirmatory Factor Analysis (CFA)}

CFA is used to measure the uniqueness and relevance of the model, and has Chi-squared results $=385.165$ with 237 degrees of freedom statistically significant. GFI $=0.906$; $\mathrm{TLI}=0.931 ; \mathrm{CFI}=0.941$ are $>0.9 ; \mathrm{CMIN} / \mathrm{df}=1.625$. The RMSEA $=0.046(<0.08)$. According to Giao and Vương (2019), with the four analytical indices mentioned above, the model of exploration is considered to be good fit and to achieve uni-directionality.

Convergence value measurement: The standardized weights of the scale are high $(>0.5)$, and the weights (unstandardized) are statistically significant bsecause $\mathrm{P}$ values are $<5 \%$ (Giao \& Vương, 2019). The measurement of the satisfaction of visitors to the city of Bao Loc has reached convergence. The results also show that the correlation coefficient of the TAN concept with other concepts are statistically significant. Therefore, the authors abandon this concept and conduct a second CFA analysis.

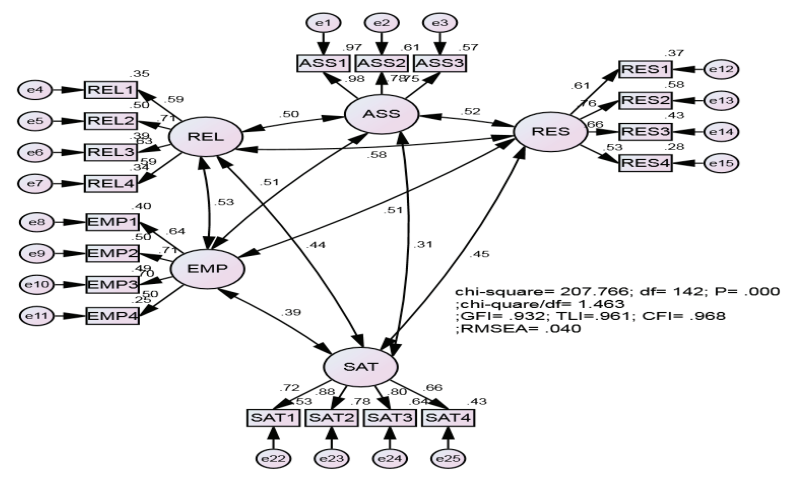

Figure 1: Second CFA result of Bao Loc City's service quality (standardized)

Measuring the uniqueness and relevance of the second CFA model: Analysis confirms that CFA has Chi-squared results $=207,766$ with 142 degrees of freedom statistically significant. GFI indices $=0.932 ; \mathrm{TLI}=0.961 ; \mathrm{CFI}=0.968$ are all $>0.9$; CMIN / $\mathrm{df}=1.463$. The RMSEA $=0.040(<$ 0.08 ) (Giao \& Vương, 2019). The model is good fit and is uni-directional.

Reliability measurement: With the above calculated reliability of the groups after the EFA, the Cronbach's Alpha values of the factor groups are found to range from 0.722 to 0.860 . The scale therefore achieves reliability.

Measure the convergence value at the second CFA: The standardized weights of the scale are high $(>0.5)$, and the weights (unstandardized) are statistically significant (Giao $\&$ Vương, 2019). The measuring variables of the satisfaction of visitors to Bao Loc City are convergent. The analysis also showed that the correlation coefficient of each pair statistically significant different from the one in the $95 \%$ reliability, ensuring the convergence value.

Distinctive value: The results of differential validation of variables in the critical model are shown in Table 4. All estimates correlated with the standard error (SE) statistically significant, so the correlation coefficient of each pair of concept differs from the one at $95 \%$ reliability. Consequently, concepts gain distinctive values.

Though the results of CFA measurement scale of tourism services in Bao Loc, Reliability, Responsiveness, Empathy and Assurance are in good fit, reaching unidirectional, ensuring convergence, reliability and distinctiveness.

Table 4: Result of distinctive values between factors in the model

\begin{tabular}{|l|l|l|c|c|c|c|c|}
\hline & & & Estimate & S.E. & C.R. & P & Label \\
\hline REL & $<-->$ & ASS & 0.227 & 0.039 & 5.749 & $* * *$ & \\
\hline ASS & $<-->$ & RES & 0.267 & 0.044 & 6.107 & $* * *$ & \\
\hline REL & $<-->$ & EMP & 0.138 & 0.030 & 4.669 & $* * *$ & \\
\hline EMP & $<-->$ & SAT & 0.118 & 0.027 & 4.301 & $* * *$ & \\
\hline RES & $<-->$ & SAT & 0.184 & 0.037 & 5.034 & $* * *$ & \\
\hline EMP & $<-->$ & RES & 0.151 & 0.032 & 4.717 & $* * *$ & \\
\hline REL & $<-->$ & RES & 0.205 & 0.039 & 5.292 & $* * *$ & \\
\hline REL & $<-->$ & SAT & 0.157 & 0.033 & 4.783 & $* * *$ & \\
\hline EMP & $<-->$ & ASS & 0.192 & 0.035 & 5.423 & $* * *$ & \\
\hline ASS & $<-->$ & SAT & 0.164 & 0.036 & 4.537 & $* * *$ & \\
\hline
\end{tabular}

(Source: Visitor survey in 2019)

\subsection{Structural equation modeling (SEM)}

\subsubsection{Structural equation modeling (SEM)}

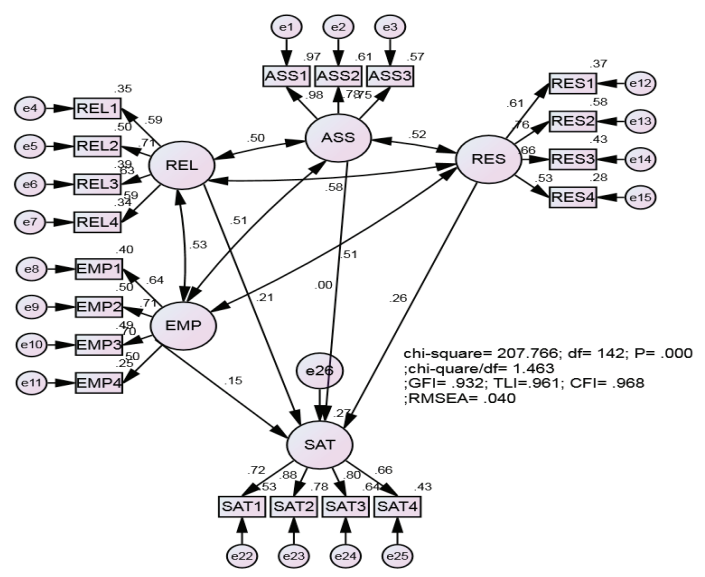

Figure 2: Test results of the SEM for service quality of Bao Loc City (standardized) 
The study uses the structural equation modeling (SEM) to assess the relevance of the research model and test relations in the model. The results of the SEM analysis with $\mathrm{df}=142$, Chi-square $=207,766$ and Chi-square $/ \mathrm{df}=1,463$ $<2$, RMSEA $=0.04$ should confirm that the overall model had a good fit.

However, the $p$ value of Assurance concepts that affect Satisfaction is greater than 0.1 . Thus, the relationship of concepts has not reached the theoretical expectation. In order to choose a more suitable model, relationships that are not statistically significant will be excluded from the model. Removing this group of factors from the model and running the SEM test again, we have: the final study model after eliminating relationships was not statistically significant for chi-square values $=142.044$ with $\mathrm{p}$ value $=0.002$, chisquare $/ \mathrm{df}=1.453, \mathrm{GFI}=0.944 ; \mathrm{CFI}=0.969 ; \mathrm{TLI}=0.962$ and RMSEA $=0.039$ indicates that the overall model had a good fit..

\subsubsection{Research Hypotheses Testing}

The standardized weightings are positive so it really affects the satisfaction of visitors to Bao Loc City. Responsiveness had the greatest impact on satisfaction $(\beta=$ $0.260)$, next is Reliability $(\beta=0.239)$ and finally Empathy $(\beta=0.204)$. The unstandardized results of the parameters show that the relationships are statistically significant $(\mathrm{p}<$ 0.1 ), that is, the hypotheses $\mathrm{H}_{2}, \mathrm{H}_{3}$, and $\mathrm{H}_{4}$ in the model are acceptable.

\subsubsection{Bootstrap}

The study uses the Bootstrap method with a repeated sample size of $\mathrm{N}=600$. The results of the estimation shown in Table 5 show that, although there is a deviation but a very small and stable value, in the research model is reliable.

Table 5: Bootstrap estimation results

\begin{tabular}{|c|c|c|c|c|c|c|c|c|}
\hline \multicolumn{2}{|c|}{ Relationship } & Estimates & SE & SE-SE & Mean & Bias & SE-Bias & CR \\
\hline SAT <--. & REL & 0.207 & 0.119 & 0.003 & 0.202 & -0.005 & 0.005 & -1 \\
\hline SAT <--. & EMP & 0.152 & 0.115 & 0.003 & 0.146 & -0.005 & 0.005 & -1 \\
\hline SAT <--. & RES & 0.257 & 0.109 & 0.003 & 0.261 & 0.005 & 0.005 & 1 \\
\hline
\end{tabular}

According to the results of test hypothesis studies for the destination of Bao Loc City, hypothesis $\mathrm{H}_{2}$ which has the positive relationship between Reliability and Satisfaction of tourists and hypothesis $\mathrm{H}_{3}$ which has the positive relationship between Empathy and Satisfaction are all accepted and hypothesis $\mathrm{H}_{4}$ has the positive relationship between Responsiveness and Satisfaction. These three pairs are of theoretical value.

From the theoretical model, the study identified the actual model:

\section{$f=\{$ Reliability, Empathy, Responsiveness $\}$}

\section{Discussion}

The quality of service provided is one of the factors that affect customer satisfaction. A well-provisioned service will increase customer satisfaction and vice versa. Improved service quality will lead to improved customer service and customer satisfaction.

Research models may show practical applications that affect visitor satisfaction as follows:

First, Responsiveness: this factor has the strongest impact on the model, and is highly dependent on the organizers providing products/services at attractions, resorts, fun points entertainment, etc. Diversified products and services which meet the expectations of visitors will contribute to tourists satisfaction.

Second, Reliability: it demonstrates the ability to provide timely, appropriate services, ie, food and lodging providers, convenient communication system, and provision of transportation between destinations and resorts. Visitors also pay attention to the security and safety when traveling and visiting the tourist sites; should management organizations and tourism business do well, this will build visitors' trust, ensuring peace of mind when traveling to Bao Loc. In this study, Reliability is the second most trusted component of the study after Responsiveness.

Third, Empathy: it refers to the style of professional service, courtesy of the staff through attention to visitors, quick to understand and meet the needs of visitors, and create a sense of safety for visitors. Frequent staff training, especially professional style, courtesy, experience and deep understanding of the front line towards the needs of visitors will help visitors be more satisfied.

Amazingly, the research found that Tangibles and Assurance do not affect tourists' satisfaction towards Bao Loc City. It may come from the situation in which Bao Loc City develop tourism rapidly in recent years. Also, all the natural landscapes and cultural attractions are around the city, so tourists can explore and enjoy settings without 
any support from the local tourism organizations such as convenient hotels, tour guides, food instructions, etc. However, in the coming years, local tourism management need to pay attention to these important points to cover full service packages to visitors.

\section{Managerial Implications and Conclusion}

\subsection{Managerial Implications}

Based on the results of the research, the above discussion, and results by Giao and Anh (2014), the study could contribute some key recommendations to managers and tour operators in Bao Loc City. From the results, in general, tourists just assess the service quality of Bao Loc City tourism rather highly. This, in turn, helps tourism managers to better manage their accommodations, and increase the number and quality of accommodations at affordable prices. In addition, there should be more transportation, communication and guidance to meet the needs of visitors when visiting the city. Besides, around the sights, it is necessary to create more convenient services for visitors such as seats, public toilets, cashpoints, green space, landscape, etc.

Tourism managers and organizations also need to pay attention to investing more in art performances bearing bold Bao Loc culture to visitors, not only in Bao Loc, but also in the specialized villages in Bao Loc. This is a way for visitors to be in harmony with the people of Bao Loc; visitors will be more satisfied because their needs are to see and participate in the activities. In addition, it is necessary to develop more specific products as souvenirs of Bao Loc; these products only appear in Bao Loc, having a unique souvenir gift will make visitors more satisfied.

The Empathy is underestimated, so it is necessary to increase the training of tourism staff at tourist sites of Bao Loc, Bao Lam. The provision of food, drink and other services such as safety, communication with customers should be given special attention. As this team will contribute to improving the quality of service, making visitors more satisfied when they come to Bao Loc is important.

\subsubsection{Responsiveness}

The visitors' assessment of the Responsiveness is close to the needs of the travelers (mean of 3.5 to 3.8). To increase tourists' satisfaction with the service provider's responsiveness, regular training is required so that staff can know and quickly understand tourists' needs and respond to them promptly (Giao \& Phuc, 2015; Giao \& Quang, 2018). The training and training staff closely relate to the professional service style, but also indirectly affect the sense of hospitality when tourists travel in Bao Loc (Giao \& Loc, 2016). When the needs of visitors are met timely, visitors will feel more satisfied.

\subsubsection{Reliability}

The visitors' assessment for Reliability is not high with the visitors' needs for trust (the mean of about 3.5). To increase the tourists' satisfaction about the reliability of the tourism businesses, the price should be adjusted to suit room quality, which means that for different types of rooms, the price should be the most appropriate for the room type. As the same time, enhancing other facilities, ensuring the cleanliness of guests' rest, leisure, and entertainment will help to improve the satisfaction.

\subsubsection{Empathy}

The observed variables in the Empathy scale were not highly evaluated (mean, from 3.3 to 3.5). Increasing value of the galleries through ancient artifacts, myths, specialties, and souvenirs bearing the characteristics of the city will attract more tourists; the visit to Bao Loc will, thus, leave a deep impression on visitors, the forms of trade and commerce that refer to the past will create more emotions, and that will build visitor's satisfaction and motivate them to return to find other interesting emotions in Bao Loc.

\subsection{Conclusion}

This research has identified the factors that affect tourists satisfaction towards Bao Loc City as follows: The most influential one is Responsiveness, followed by Reliability and finally, Empathy. Based on the results of the study, the SEM linear structure model shows visitors' perceptions about each element of the components that affect their satisfaction. It has suggested some ideas for managers and tourism business organizations to improve service quality to maximize tourists satisfaction. When tourists satisfaction is high, the likelihood they will return to Bao Loc City is high (Giao, Phuc \& Ngan, 2018). Bao Loc City brand is increasingly popular, not only in the country, but also internationally, which contributes to developing tourism activities of the city. Finally, the research has applied an experiment of service quality to a tourism destination, typically Bao Loc City in the present context.

\subsection{Limitation and Suggestions for Further Studies}

The research has made a number of contributions in understanding the factors that affect tourists' satisfaction towards Bao Loc City. However, the research still has some the following limitations: (1) the sample size is rather modest; (2) the convenient sampling method may reduce the generalization. Future studies will increase the level of representation, increase the sample size and expand the scope of the survey to other tourist sites in Bao Loc City and contribute to the completion of this study. 


\section{References}

Cronin J. J., \& Taylor S. A. (1994). SERVPERF versus SERVQUAL: Reconciling performance - Based and Perceptions-minusexpectations measurement of service quality. Journal of Marketing, 58(January), 125-131.

Foody. (2019). Bao Loc is the ideal place for tourists. https:// dananggreen.com/en/news/218-bao-loc-is-the-ideal-place-fortourists.html. Retrieved on Jan 20, 2020.

Gartrell, R. B. (1994). Destination Marketing for Convention and Visitor Bureaus (2nd ed.). Dubuque: Kendall/Hunt Publishing Co.

Giao, H. N. K., \& Vu, N. T. (2011). Customers Satisfaction on the Service Quality of Vinatex-mart. Economic Development Review, 253, 9-16. DOI: 10.31219/osf.io/r7xfe.

Giao, H. N. K. (2004). Services Marketing- 5 Gaps in Services Quality Model. (Vietnamese). Statistical Publishing.

Giao, H. N. K. (2011). Textbook Tourism Marketing. HoChiMinh City, Vietnam: HoChiMinh City General Publisher. DOI: 10.31219/osf.io/z4yhd

Giao, H. N. K. (2017). Customer Satisfaction and Quality of Vietnam Airline Domestic Services. International Journal of Quality Innovation, 3(1), 1-11, DOI 10.1186/s40887-017-00194, https://ideas.repec.org/a/spr/ijoqin/v3y2017i1d10.1186_ s40887-017-0019-4.html

Giao, H. N. K. (2018). Decision to purchase online airline tickets in Ho Chi Minh City, Vietnam. National Academy of Managerial Staff of Culture and Arts Herald, 4, 459-470. http://jrhnamsca. icu/index.php/hnamsca/issue/view/1. DOI: 10.31219/osf.io/ fzh5v.

Giao, H. N. K. (2018). Monographic Book Measuring Service Quality in Vietnam - from the Customers Angle. Hanoi, Vietnam: Finance Publishing. DOI: 10.31219/osf.io/cqh68. ISBN: 978-604-79-1788-4

Giao, H. N. K. (2018a). Decision to choose fast food restaurants of the young people in HCMC, Vietnam. National Academy of Managerial Staff of Culture and Arts Herald, 4, 471-485. http://jrhnamsca.icu/index.php/hnamsca/issue/view/1. DOI: 10.31219/osf.io/xgv2k.

Giao, H. N. K. (2018b). Factors Influencing Customer Behavior of Butter Oil Substitute in Vietnam. Journal of Business and Economics, 9(3), 266-274, DOI: 10.15341/jbe(21557950)/03.09.2018/005. DOI: 10.31219/osf.io/gn6em

Giao, H. N. K. (2018c). Study of the Factors Affecting Customers' Loyalty for Gym Service at K.I.M Center, Vietnam. International Journal of Scientific Engineering and Research, 6(12), 67-76. http://www.ijser.in/archives/v6i12/IJSER18459. pdf. DOI: $10.31219 / 0 s f . i o / 57 g 8 a$.

Giao, H. N. K. (2018d). Vietnamese consumers' attitude on television advertisement of skin care. National Academy of Managerial Staff of Culture and Arts Herald, 4, 486-491. http://jrhnamsca.icu/index.php/hnamsca/issue/view/1. DOI: 10.31219/osf.io/a2bn9.
Giao, H. N. K. (2019a). Attidtude and Intention to buy VietGAP vegetables of inhabitants in HoChiMinh City. International Journal of Agricultural Economics, 4(3), 125-134. doi: 10.11648/j.ijae.20190403.16. file://C:/Users/Prof.\%20Giao/ Downloads/10.11648.j.ijae.20190403.16.pdf

Giao, H. N. K. (2019b). Customer Satisfaction towards ATM Services: A Case of Vietcombank Vinh Long, Vietnam. Journal of Asian Finance, Economics and Business, 6(1), 141-148. http://doi.org/10.13106/jafeb.2019.vol6.no1.141

Giao, H. N. K. (2020). Customer Satisfaction at Tiki.vn E-Commerce Platform. Journal of Asian Finance, Economics and Business, 7(4), 173-183. https://doi.org/10.13106/jafeb.2020.vol7. no4.173

Giao, H. N. K., \& Anh, H. D. T. (2014). The Situation and some Solutions to Develop the Tourism of Dong Nai Province. Journal of Binh Duong Economics and Technology, 8, 12-26.

Giao, H. N. K., \& Binh, N. V. (2011). Textbook Profession in Restaurant (Vietnamese). HoChiMinh City, Vietnam: HoChiMinhCityGeneralPublishing.DOI:10.31219/osf.io/hqjaf

Giao, H. N. K., \& Binh, N. V. (2014). Textbook Profession in Restaurant (Vietnamese). Hanoi, Vietnam: Statistical Publishing.. DOI: 10.31219/osf.io/r35jg

Giao, H. N. K., \& Hao, N. H. (2011). Measuring the Quality Service at Whitesand Resort. Journal of Finance and Marketing Research, 3, Apr 2011, 56-65. DOI: 10.31219/osf.io/57kdr

Giao, H. N. K., \& Loc, N. Q. (2016). The inpact of Work Pressure and Work Motivation on the Working Effectiveness at Quê Hương Liberty Hotel Staff. Journal of Vietnam Tourism, 28 Jan 2016, p.3.

Giao, H. N. K., \& Phuc, N. P. H. (2015). Measuring the Student Satisfaction of the Training Quality at the Faculty of Tourism, University of Finance and Marketing in the period of 20102013. Journal of Finance and Marketing Research, 28, 67-74. DOI: 10.31219/osf.io/chtpk

Giao, H. N. K., \& Quang, Y. K. (2018). The solutions to train the tourism human resources at the colleges and vocational schools following the requirements of activate Mutual Recognition Arrangement on Tourism Professionals (MRA-TP). National Conference on Training tourism human resources following the Degree No 08/NQ-TW- Ministry of Culture - Sport and Tourism, on the 1st of Dec 2017 at Hanoi, pp. 263-272. DOI: 10.31219/osf.io/b53tq

Giao, H. N. K., \& Sang, H. T. (2018). Factors solicit domestic trourists to the Con Dao Island, Ba Ria - Vung Tau province. Vietnam Trade and Industry Review, 15, Dec 2018, 131-137. DOI: $10.31219 /$ osf.io/gmxb3.

Giao, H. N. K., \& Son, L. T. (2012). Factors Affecting the Satisfaction of Visitors to Dalat Flower Festival 2012, Journal of Economic Development, 214, October 2012, 144-156. DOI: 10.31219/osf.io/p93ye

Giao, H. N. K., \& Son, L. T. (2014). Textbook Strategic Management in Tourism Organizations (Vietnamese). Hanoi , Vietnam: Statistical Publishing. DOI: 10.31219/osf.io/tp9uv 
Ha Nam Khanh GIAO, Tran Dieu HANG, Le Thai SON, Dinh KIEM, Bui Nhat VUONG /

Journal of Asian Finance, Economics and Business Vol 7 No 7 (2020) 269 - 277

Giao, H. N. K., \& Son, L. T. (2015). Exploring the factors affecting the satisfaction of tourists going to wooden traditional village Kim Bong- Hoi An. Journal of Binh Duong Economics and Technology, 9, 1-10. DOI: 10.31219/ osf.io/dgke2.

Giao, H. N. K., \& Son, L. T. (2018). MICE tourism developmentExamination from the supply side in Dalat City, Vietnam. Global and Stochastic Analysis, 5(6), Special Issue 2018, 371390. DOI: 10.31219/osf.io/r36yf.

Giao, H. N. K., \& Vuong, B. N. (2019). Textbook for Master Degree Research Methods in Business- Updated with SmartPLS. Hanoi, Vietnam: Finance Publishing. DOI: 10.31219/osf.io/ hbj3k. ISBN: 978-604-79-2154-6

Giao, H. N. K., Binh, N. V., \& Tung, N. S. (2014). Textbook Business Management in Hotels (Vietnamese). Hanoi, Vietnam: Statistical Publishing. DOI: 10.31219/osf.io/7ysem

Giao, H. N. K., Hoai, A. T., \& Vinh, P. Q. (2019). Management of Services Business- From the Angle of Marketing. Hanoi, Vietnam: Communication-Information Publishing. DOI: 10.31219/osf.io/98hrd. ISBN: 978-604-80-3905-9

Giao, H. N. K., Hoan, N. C., Dung, T. Q., Vinh, N. L., \& Anh, L. T. L. (2014). Textbook Travel Business Management (Vietnamese). Hanoi, Vietnam: Statistical Publishing. DOI: 10.31219/osf.io/87unw

Giao, H. N. K., Kiem, D., Son, L. T., \& Dung, T. Q. (2018). Satisfaction of tourists to Hoi An ancient town, Vietnam. Global and Stochastic Analysis, 5(8), Special Issue 2018, 123136. DOI:10.31219/osf.io/sbjev.

Giao, H. N. K., Phuc, N. P. H., \& Ngan, N. T. K. (2018). The affect of destination image factors on revisit intention of domestic tourists at Bà Rịa - Vũng Tàu. Global Conference on Business, Hospitality and Tourism Research (GLOSEARCH 2018), October 2-5, 2018 at the Hoa Sen University, Ho Chi Minh City, Vietnam, 143-157.

Giao, H. N. K., Trung, B., \& Truong, P. X. (2019). Outbound service quality at Wan Hai Lines. Journal of Asian Finance, Economics and Business, 6(1), 177-185. http://doi.org/10.13106/ jafeb.2019.vol6.no1.177

Giao, H. N. K., Vuong, B. N., \& Quan, T. N. (2019). The influence of website quality on consumer's e-loyalty through the mediating role of e-trust, esatisfaction, and perceived enjoyment: An evidence from online shopping in Vietnam. Uncertain Supply Chain Management, 8(2), 351-370. DOI: 10.5267/j.uscm.2019.11.004.
Giao, H. N. K., Vuong, B. N., Huan, D. D., Tushar, H., \& Quan, T. N. (2020). The Effect of Emotional Intelligence on Turnover Intention and the Moderating Role of Perceived Organizational Support: Evidence from the Banking Industry of Vietnam. Sustainability, 12(5), 1857-1882. doi:10.3390/su12051857.

Lovelock, C., \& Wirtz, J. (2004). Services Marketing - People Technology - Strategy (5 ${ }^{\text {th }}$ Edition). Upper Saddle River, NJ: Prentice Hall.

Medlik, S., \& Middleton, V. T. C. (1973). The Tourist Product and its Marketing Implications. International Tourism Quarterly, No. 3. Reprinted in Burkart, A. J. and Medlik S. (eds.) (1975). The Management of Tourism. London: Heinemann.

Page, S., \& Connell, J. (2006). Tourism: A Modern Synthesis. London: Thompson Learning.

Parasuraman, A., Zeithamlm, V. A., \& Berry, L. L. (1985). A conceptual model of service quality and its implications for future research. Journal of Marketing, 49 (fall), 41-50.

Parasuraman, A., Zeithamlm, V. A., \& Berry, L. L. (1988). SERVQUAL: A multiple-item scale for measuring consumer perception of service quality. Journal of Retailing, 64(1), 12-40.

Rubies, E. B. (2001). Improving public-private sectors cooperation in tourism: A new paradigm for destinations. Tourism Review, $56(3 / 4), 38-41$.

Son, L. T., \& Giao, H. N. K. (2014). The Factors Affecting the Development of MICE in Dalat City. Economic Development Review, 290, 91-110. DOI: 10.31219/osf.io/s4hgw

Son, L. T., \& Giao, H. N. K. (2018). The model of developing MICE in Vietnam from the resources factors. Vietnam Trade and Industry Review, 1 (Jan.), 234-239. DOI: 10.31219/osf.io/u4bxw.

Svensson, G. (2002). A triadic network approach to service quality. Journal of Services Marketing, 16(2), 158-179.

Vietnam National Administration of Tourism. 2020. http://www. vietnamtourism.gov.vn/english/index.php/tags/Lam-Dong, retrieved Feb 20, 2020

Vuong, B. N., \& Giao, H. N. K. (2019). The impact of brand globalness on consumers purchase intention and the moderating role of consumer ethnocentrism an eveidence from Vietnam. Journal of International Marketing, 32(1), 47-68. DOI: 10.1080/08961530.2019.1619115.

Zeithaml, V. A., Parasuraman, A., \& Berry, L. L. (1990). Delivering Quality Service, Balancing Customer Perceptions and Expectations. New York, NY: Free Press. 